\title{
Human capital and economic growth in South Africa: A cross-municipality panel data analysis
}

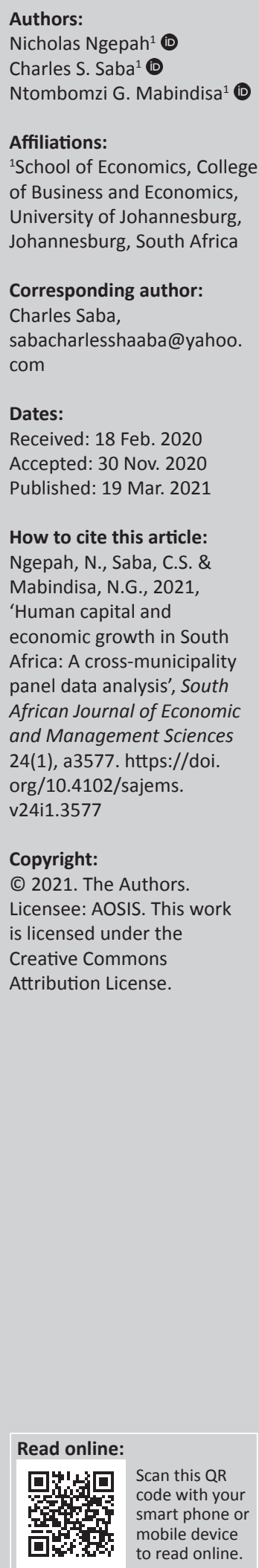

Background: In the literature, human capital has been identified as a key economic variable that is needed to promote growth; hence this study explores the components of human capital, that is, different skill levels in order to capture the real effect of the employed labour on economic output across the municipalities of South Africa.

Aim: This study investigates the effect of human capital of employed labour on economic output and growth in South Africa.

Setting: The study focuses on the balanced panel of 269 South African municipalities for the period 1993 to 2016.

Methods: The study utilises panel causality test and the generalised method of moments estimation techniques.

Results: A panel causality test confirms bidirectional causality between human capital and total output, as well as between total employment and total output. The resultant aggregate findings suggest that human capital has a positive and a significant impact both on total output and economic growth. The disaggregated proxy of human capital shows that higher levels of skilled employment is associated with higher total output and economic growth.

Conclusion: The findings of the effect of skilled employment on economic growth are in line with theoretical literature and therefore the study concludes that human capital in the form of skilled labour has a positive effect on both economic output and growth in South Africa. This informs policy to prioritise the upskilling of the labour force in order to contribute positively towards value-generating economic activities in South Africa.

Keywords: human capital; economic growth; panel causality; South Africa.

\section{Introduction}

This study focuses on investigating the effect of human capital on economic growth in South Africa, making use of a balanced panel of 269 South African municipalities for the period 1993 to 2016. The approach used in this study differs from previous studies because it examines the skills component of human capital and its impact on economic growth. Economic growth literature highlights three mechanisms that show a causal relationship between the education component of human capital and economic growth. Firstly, education is a key instrument that shapes the human capital fibre, equipping the labour force for higher productivity levels (Mankiw, Romer \& Weil 1992). Secondly, education increases the innovative capacity of the economy and brings knowledge of new technologies, products and processes which then promote efficient production activities that boost economic growth. This view is supported by theories of endogenous growth developed by Lucas (1988), Howitt and Aghion (1998) and Romer (1990). Lastly, education facilitates the diffusion and transmission of knowledge needed to understand and process new information, as well as successfully implement new technologies to promote economic growth (Benhabib \& Spiegel 1994; Nelson \& Phelps 1966). Acemoglu (2009) notes that in the case of farming, educated farmers accept and adapt easily to the utilisation of new technology or seeds in order to increase productivity and income levels.

The South African economic landscape has been characterised by different levels of economic growth from the democratic transition period which saw a lifting of sanctions, the ushering in of open trade and increased levels of foreign direct investments (FDI). The political shift accelerated the country's position as a gateway to the African continent by diversifying the economy beyond the mining and agricultural sectors to expand the financial services, retail and manufacturing sectors. A commodity boom period between 2004 and 2007 also affirmed the country's global 
standing in trade (Frankel, Smit \& Sturzenegger 2008). However, the global financial crisis of 2008-2009 resulted in a significant decline in South Africa's exports and jobs (South African Reserve Bank 2009).

As South Africa continues to experience poverty, inequality and unemployment, the government developed a national document - National Development Plan (NDP) - to mitigate their effect on the economy. The NDP regards investment in human capital as a critical instrument that will reduce inequality levels and prepare people to participate in incomegenerating economic activities (National Planning Commission 2011). An educated, skilled and healthy workforce is an important factor in realising higher levels of total output.

According to the World Bank (2015), developing economies have been reported as having steady economic growth post the 2008 to 2009 economic crises. The performance of the South African economy was reported as lagging behind other middle-income countries like Brazil, India and China. The post-apartheid South African economy has been characterised by high levels of unemployment, inequality and poverty. This is despite impressive economic growth rates recorded between 2005 and 2008. Data from Statistics South Africa (Stats SA) show that employment growth has not reflected similar improvements (Mahadea \& Simson 2010). Contrary to the gross domestic product (GDP) growth trend of developing countries where labour-intensive industries in the primary and secondary sectors are the main contributors, the South African GDP growth is led by the tertiary sector (Stats SA 2016:Q42016). Imbs (2013) considers this structural shift as 'premature de-industrialisation'. South Africa's large pool of low-skilled and semi-skilled labour is likely to be rendered redundant in some of the employment opportunities offered by the tertiary sector. This is similar to Witherick's (1999) view of the negative impact of rising service sector jobs on low-skilled and semi-skilled people of the United Kingdom in the 1980s.

An inadequately educated workforce has been highlighted as one of the problematic factors of doing business in South Africa (Schwab 2017). This deficiency has the potential of containing FDI and capital inflows. In this regard, gross domestic investment as a percentage of GDP also decreased from $28 \%$ to $19 \%$ between 1980 and 2016 (South African Reserve Bank 2018). Borensztein, Gregorio and Lee (1998) inform that the effect of the flow of advanced technology through FDI is determined by the absorptive capability of the hosting economy or country.

Denison (1985) confirmed that an extended number of years in school between the years 1929 and 1982 explained about $25 \%$ of income per capita growth in the United States. However, the quality of tertiary education in South Africa has been reported as less capable of adequately preparing people for effective participation in the labour sector (Fedderke, De Kadt \& Luiz 2003). The alignment of the basic education policy with industry requirements would give basic skills to secondary school learners to meet entrance requirements of the labour sector. Secondly, the increasing growth momentum of the tertiary sector (services) requires matching skills from the labour force. Lastly, increasing mechanisation and technological advancement of production processes require specialised skills. It is therefore important that the set of skills provided by South African education institutions is in line with the demand for labour required by key economic sectors.

Therefore, a study to determine the effect of human capital on South Africa's economic growth is important to inform policy. Some empirical studies (Barro et al. 1993; Bassanini \& Scarpetta 2002) use education levels, school enrolment, education attainment and number of years in school as proxies for human capital. This study will use the skill levels (skilled, semi-skilled and low-skilled) in order to capture the real effect of the employed labour on economic output across the municipalities of South Africa. The skills proxy is also used by Hanushek, Schwerdt and Wiederhold (2015) in investigating the returns associated with different measures of cognitive skills (human capital). Measuring human capital by different skill levels includes those with school attainment, individual ability and labour market experience (Hanushek et al. 2015). This is in line with the assumption that education boosts labour productivity and equips people for ease of technological adaptation (Verspoor 1990).

To the best of our knowledge, little or no attention has been given to how human capital in the form of skills has an impact on economic output and economic growth across the 269 South African municipalities for the period 1993 to 2016. Therefore, this study contributes to filling this gap in the literature. The objective of this study is to investigate the effect of the human capital in employed labour on economic output and growth in South Africa, with a balanced panel of 269 South African municipalities for the period 1993 to 2016. This study contributes to the empirical literature in three important ways. Firstly, the direction of causality between skilled employment and total output, as well as between skilled employment and total employment, is investigated. Secondly, the dynamic panel generalised method of moments (GMM) estimation technique is introduced to investigate whether human capital in the form of skills has an impact on economic output and economic growth. Thirdly, it aims to recommend policies that will align the labour force to skill levels that have a high contribution to total output.

The remainder of the article is organised as follows: Literature review, Research methodology, Empirical results and discussion, and, finally, the Conclusion.

\section{Literature review}

Classical economic thinking on the sources of economic growth, beginning with Solow's (1957), considers labour productivity as an exogenous factor, depending on the ratio of capital and labour, and technical progress, with no regard to the role of education and skills. However, the main source 
of technological change on economic growth was not explored extensively until the 1990s, with Mankiw et al. (1992) adding human capital as a factor of production. Solow (1956), Nelson and Phelps (1966) and Lucas (1988) concur that human capital is an important factor for economic growth. However, these and other authors use different frameworks to explain the effect that human capital has on economic growth. Nelson and Phelps explain that human capital is a catalyst that accelerates productivity levels through innovation and ease of adaptation to new technological ways of manufacturing, concluding that higher endowment of human capital results in increased levels of innovation.

Engelbrecht (2003) highlights the dynamic role played by human capital both as an input in the aggregate production function and as a catalyst for innovation and technological progress. Becker, Murphy and Tamura (1990) find a negative correlation between human capital and population growth. This is further reiterated by Rosenzweig's (1990) view that developed countries are characterised by low population growth and high levels of human capital in terms of education, education attainment, on-the-job training and vocational skills. For the case of South Africa, Bhorat, Cassim and Tseng (2016) investigate the impact of education cohorts of the South African labour market on economic growth. They used the two-stage regression on a modified Cobb-Douglas production education function. They further disaggregated the labour component by education to determine the effect of each educational group on economic growth. The results of the study suggest a positive relation between growth and tertiary education. Their findings were similar to an assertion made by Van der Berg et al. (2011) that 'poverty can perpetuate itself via low educational attainment and low-quality education, resulting in dire labour market prospects, creating a vicious cycle that impedes social mobility'. A positive relationship is also reported for those with a matric certificate while the further education and training qualification holders recorded a negative relationship with growth.

A number of studies that have investigated the impact of human capital on economic growth have used different proxies, with a majority opting for the education variable as a proxy for human capital (Awad, Halid \& Yussof 2013; Barro et al. 1993). The endogenous growth model argues that a certain level of education advances technological innovation and contributes favourably towards economic growth. However, a better education resulting in higher innovation is, on its own, a function of high economic growth, thereby suggesting reverse causality (Bayraktar-Sağlam 2016; Blundell \& Bond 1998). Bils and Klenow (2000) argue that there is a high correlation between education investments and economic growth owing to a reverse causality, where higher economic growth levels result in increased investment in education.

Barro (2001) informs that there is a strong correlation between school enrolment, and long-run economic growth. Similarly, Bassanini and Scarpetta (2002) conclude that one additional year in schooling years translates into a rise in GDP per capita of $6 \%$. Blundell et al. (1999) also report on the positive contribution of manpower qualifications and skills to productivity and competitiveness. However, Murphy, Shleifer and Vishny (1991) find that the effect of human capital differs according to a selected proxy, with the use of engineers as proxy cited as having a higher effect on economic growth compared to legal professionals. Furthermore, Easterly (2001) argues that the combination of quality education, economic institutions and capital has a muting effect on growth in countries where facilitating factors like functioning markets and legal systems are not established. This shows that the value-generating effect of human capital may be limited by the absence of enabling factors. The mismatch of allocating cognitive skills to socially unproductive activities may render human capital unfruitful to economic growth (Pritchett 2001).

The lack of a universally aligned proxy for human capital has led to a debate as to whether human capital should be treated as an ordinary input to the aggregate production function. The use of different proxies like school enrolment rates, educational attainment, and completion of primary, secondary or tertiary education has often led to different conclusions with respect to the impact of human capital on economic growth. Furthermore, the relationship between the two variables is compromised by proxies used such as the 'average years of school attendance' in which each extra year in education, whether at primary, secondary or tertiary level, is considered to yield an equal additional benefit to total output.

Other empirical studies (Abbas 2001; Borojo \& Jiang 2016; Petrakis \& Stamatakis 2002) disaggregate the education proxy into different levels - primary, secondary and tertiary in order to detect the impact of each level on economic growth. Results from these studies suggest that education at primary level has a positive contribution to economic growth of least developed countries while tertiary education has a significant contribution to developed countries where innovation and adoption of technology is critical. A similar outcome was reported by Gyimah-Brempong, Paddison and Mitiku (2006). This study follows a similar pattern in which a proxy for human capital (skills) will be divided into three categories of skilled, semi-skilled and low-skilled employment. However, this study proxy for human capital is measured from the labour market in terms of various socioprofessions and the number of years of education required to attain such

\section{Research methodology}

In order to achieve the objective of this study, three processes were used, which include: a panel Granger causality test and the GMM estimation techniques. This study applies the recently developed Dumitrescu and Hurlin (2012) panel causality test to investigate the direction causality between the variables of interest. This causality test was used because it takes into account the heterogeneous nature of the panel data. The study further estimated GMM and system GMM (interested readers are referred to Arellano \& Bond 1991; 
Arellano \& Bover 1995; Blundell \& Bond 1998 for more details). This method was used because according to Baum, Schaffer and Stillman (2003), GMM estimator is more efficient than the simple instrumental variable techniques. Besides, the GMM panel estimator exploits the time-series variation in the data, accounts for unobserved country-specific effects, reduces finite sample biases and controls for endogeneity of all the explanatory variables.

\section{Functional form and model specification}

Theoretical research on the determinants of economic growth has highlighted the importance of human capital (Solow 1956; Nelson \& Phelps 1966; Lucas 1988). Endogenous growth models such as the augmented Solow growth model presented human capital as a critical factor of economic growth. In order to estimate the impact of human capital on economic output and growth, the study will use a theoretical framework of the Cobb-Douglas production function. According to Solow's neoclassical aggregate production function, total output $(\mathrm{Y})$ is a function of capital $(\mathrm{K})$ and labour (L) inputs shown as:

$$
Y=F(K, L)
$$

[Eqn 1]

Neoclassical economists like Mankiw et al. (1992) have shown the flexibility of this framework to allow the inclusion of different economic variables like technology (A) and human capital $(\mathrm{H})$ as shown below:

$Y_{t}=A_{t} K_{t}^{\alpha} L_{t}^{\beta} H_{t}^{\mu}$

[Eqn 2]

For the purpose of this study, the Cobb-Douglas production function will be adjusted to include three different skill levels (skilled, semi-skilled and low-skilled) as proxies for human capital. Three methods of analysis will be utilised. The first method is a widely utilised ordinary least squares (OLS), with equations for total output at level and log transformed presented as:

$$
\text { Output }_{i, t}=\beta_{0}+\beta_{1} S_{i, t}+\beta_{2} S S_{i, t}+\beta_{3} L S_{i, t}+\beta_{4} \text { Capital }_{i, t}+\varepsilon_{i,}
$$

[Eqn 3]

$$
\text { L.Output }_{i, t}=\beta_{0}+\beta_{1} \text { L.S }_{i, t}+\beta_{2} L . S S_{i, t}+\beta_{3} L . L S_{i, t}+\beta_{4} \text { L.Capital }_{i, t}+\varepsilon_{i, i}
$$

[Eqn 4]

Equation 3 and Equation 4 show logarithms of all variables, with L.Output showing a logarithm of total output. $\beta_{0}$ is a constant term while $\beta_{1}$ L.S $S_{i, t}$ shows a logarithm of skilled employment, $\beta_{2} L . S S_{i, t}$ represents a logarithm of semiskilled employment and $\beta_{3} L . L S_{i, t}$ depicts a logarithm of low-skilled employment - all these variables are proxies for human capital at different skill levels. The variable $\beta_{4} L$. Capital $_{i, t}$ is a logarithm of gross fixed capital formation and $\varepsilon$ is a random error term.

Borojo and Jiang (2016) argue that there is a possibility of endogeneity when dealing with economic growth due to its dynamic phenomenon. The existence of endogeneity will be evaluated by a Granger causality test. For the purpose of this study, the Dumitrescu-Hurlin test for Granger non-causality will be done between economic output and human capital (skilled employment). An equation depicting causality from economic output to human capital is presented as:

$$
\begin{aligned}
& S_{i, t}=\alpha_{i, t}+\sum_{K-1}^{K} \gamma^{(k)} S_{i, t-k}+\sum_{K=1}^{K} \beta_{i}^{(k)} \text { output }_{t-k}+\varepsilon_{1 i, t} \\
& i=1,2, \ldots . N ; t=1,2 \ldots, T
\end{aligned}
$$

[Eqn 5]

In Equation 5, output is a proxy for economic growth, $S$ is skilled employment (a proxy for human capital), $\gamma$ and $\beta$ are the slope coefficients, $i$ represents each municipality in a panel, $t$ is the year in the panel, $K$ is the number of lag length, $\alpha$ is the intercept of the equation and $\varepsilon$ is an error term.

Similarly, the equation showing causality from human capital to economic output is presented as:

$$
\text { ouput }_{i, t}=\alpha_{i, t}+\sum_{K=1}^{K} \gamma^{(K)} \text { ouput }_{i, t-K}+\sum_{K=1}^{K} \beta_{\mathrm{i}}^{(K)} s_{i, t-K}+\varepsilon_{2 i, t}
$$

[Eqn 6]

These equations will test the direction of causality between the two variables (human capital and total output). Another causality test is between total output and total employment and between total employment and total output. Equations are shown below. Also, an assumption is that lag orders of $K$ are identical for all cross-section units of the panel. $K$ represents the number of lags.

$$
\begin{aligned}
S_{i, t}= & \alpha_{i, t}+\sum_{K-1}^{K} \gamma^{(k)} S_{i, t-k} \\
& +\sum_{K=1}^{K} \beta_{i}^{(k)} \text { output }_{t-k}+\varepsilon_{1 i, t} \\
& i=1,2, \ldots . N ; t=1,2 \ldots, T
\end{aligned}
$$

$$
\begin{aligned}
\text { output }_{i, t}= & \alpha_{i, t}+\sum_{K-1}^{K} \gamma^{(k)} \text { output }_{i, t-k} \\
& +\sum_{K=1}^{K} \beta_{i}^{(k)} \text { empl }_{-} t_{i, t-k}+\varepsilon_{2 i, t} \\
& i=1,2, \ldots ., N ; t=1,2, \ldots, T
\end{aligned}
$$

In Equation 7 and Equation 8, empl_t represents total employment. It is expected that the Granger causality test will suggest whether there is endogeneity between total output and human capital, as well between the total output and total employment. As discussed above, in the likely presence of endogeneity, a dynamic system GMM model is a preferred estimator as it is able to correct endogeneity.

The system GMM model is characterised by the presence of a lagged dependent variable $\left(\Delta L\right.$.Output $\left.t_{\mathrm{i}, \mathrm{t}-1}\right)$ on the righthand side of the equation. Therefore, Equation 9 shows the ability of the system GMM model to remove unobserved individual specific effects by first differencing $(\Delta)$ the growth equation: 
$\Delta$ L.Output $_{i, t}=\alpha_{i}+\alpha \Delta$ L.output $t_{i, t-1}$

$$
\begin{aligned}
& +\beta_{1} \Delta L . S_{i, t}+\beta_{2} L . S S_{i, t}+\beta_{3} \Delta L . L S_{i, t} \\
& +\beta_{4} \Delta L . \text { Capital }_{i, t}+\Delta \varepsilon_{i, t} \\
& i=1, \ldots, N ; t=1, \ldots T(\text { time })
\end{aligned}
$$

Furthermore, functional forms for estimating the impact of the different shares of skill levels (of total employment) on total economic output are presented as:

$$
\begin{aligned}
\Delta \text { L.Output }_{i, t}= & \alpha_{i}+\alpha \Delta \text { L.output }_{i, t-1} \\
& +\beta_{1} \Delta L . S h_{-} S_{i, t}+\beta_{2} L . S h_{-} S S_{i, t} \\
& +\beta_{3} \Delta L . S h_{-} L S_{i, t}+\beta_{4} \Delta \text { L.Capital }_{i, t} \\
& +\Delta \varepsilon_{i, t}
\end{aligned}
$$

In Equation 10, $S h_{-} S_{i, t^{\prime}} S h_{-} S S_{i, t}$ and $S h_{-} L S_{i, t}$ are shares of skilled, semi-skilled and low-skilled employment. As with models estimated for the impact of human capital on economic output, the estimation of the impact of human capital on economic growth will follow the same method. The estimation equation presented below is for the system GMM:

$$
\begin{aligned}
\Delta g_{i, t}= & \alpha_{i}+\alpha \Delta g_{i, t-1}+\beta_{1} \Delta L \cdot S_{i, t} \\
& +\beta_{2} \Delta L \cdot S S_{i, t}+\beta_{3} \Delta L \cdot L S_{i, t} \\
& +\beta_{4} \Delta L . \text { Capital }_{i, t}+\Delta \varepsilon_{i, t}
\end{aligned}
$$

The variable $g$ represents economic growth and $g_{i, t-1}$ depicts a lagged dependent variable of economic growth. Equation 12 will estimate the impact of the three different shares of skill levels (of total employment) on economic growth:

$$
\begin{aligned}
g_{i, t}= & \alpha_{i}+\alpha \Delta g_{i, t-1}+\beta_{1} \Delta L . S h_{-} S_{i, t} \\
& +\beta_{2} \Delta L . S h_{-} S S_{i, t}+\beta_{3} \Delta L . S h_{-} L S_{i, t} \\
& +\beta_{4} \Delta \text { L.Capital }_{i, t}+\Delta \varepsilon_{i, t}
\end{aligned}
$$

The study uses municipal data across six key economic sectors - agriculture, forestry and fishing; mining and quarrying; manufacturing; wholesale and retail trade; catering and accommodation; transport, storage and communication; finance, insurance, real estate and business services - for 24 years (1993-2016) of observations. All data is extracted from Quantec database - a South African based consultancy, providing an online database for macro and regional economic, industry and international trade data. Variable names and descriptions and sources are depicted in Table 2. The list of the municipalities is not included in this study in order to save space but it is available upon request.

\section{Definition of skills}

This study defines skills by profession (see Table 1). This approach is better than defining skills by educational level. It may attenuate the education quality issue and also capture elements of workplace skills accumulation. For instance, there may be people of a certain educational level who are unemployed.

\section{Empirical results and discussion}

The summary statistics presented in Table 3 show the data for the dependent variable at level (output) with an average of R941 million and varies between 0 and R42 073 million. The output growth $(g)$ averages $0.028 \%$ and varies between

\begin{tabular}{|c|c|c|c|}
\hline Variables & Meaning & Data source & $\begin{array}{l}\text { Theoretical } \\
\text { expectation }\end{array}$ \\
\hline $\begin{array}{l}\text { Output (dependent } \\
\text { variable) }\end{array}$ & $\begin{array}{l}\text { Real gross value added } \\
\text { - real output at basic } \\
\text { prices, R millions } \\
\text { constant } 2010 \text { prices } \\
(1993-2016)\end{array}$ & $\begin{array}{l}\text { Quantec } \\
\text { database }\end{array}$ & - \\
\hline Capital (K) & $\begin{array}{l}\text { Gross fixed capital } \\
\text { formation, percentage } \\
\text { change }(1993-2016)\end{array}$ & $\begin{array}{l}\text { Quantec } \\
\text { database }\end{array}$ & Positive \\
\hline Labour (Empl_t) & $\begin{array}{l}\text { Total employment } \\
\text { (Number) }(1993-2016)\end{array}$ & $\begin{array}{l}\text { Quantec } \\
\text { database }\end{array}$ & Positive \\
\hline Skilled (s) & $\begin{array}{l}\text { Employed labour in a } \\
\text { formal sector - skilled } \\
\text { (number) }(1993-2016)\end{array}$ & $\begin{array}{l}\text { Quantec } \\
\text { database }\end{array}$ & Positive \\
\hline Semi-skilled (ss) & $\begin{array}{l}\text { Employed labour in a } \\
\text { formal sector - semi- } \\
\text { skilled (number) (1993 } \\
\text {-2016) }\end{array}$ & $\begin{array}{l}\text { Quantec } \\
\text { database }\end{array}$ & Positive \\
\hline Low-skilled (Is) & $\begin{array}{l}\text { Employed labour in a } \\
\text { formal sector - low- } \\
\text { skilled (number) (1993 } \\
\text {-2016) }\end{array}$ & $\begin{array}{l}\text { Quantec } \\
\text { database }\end{array}$ & Positive \\
\hline g & Economic growth & $\begin{array}{l}\text { Author's } \\
\text { calculation: } \\
\text { Quantec }\end{array}$ & Positive \\
\hline Sh_S & $\begin{array}{l}\text { Share of skilled labour in } \\
\text { total employment }\end{array}$ & $\begin{array}{l}\text { Author's } \\
\text { calculation: } \\
\text { Quantec }\end{array}$ & Positive \\
\hline Sh_ss & $\begin{array}{l}\text { Share of semi-skilled } \\
\text { labour in total } \\
\text { employment }\end{array}$ & $\begin{array}{l}\text { Author's } \\
\text { calculation: } \\
\text { Quantec }\end{array}$ & Positive \\
\hline Sh_Is & $\begin{array}{l}\text { Share of low-skilled } \\
\text { labour in total } \\
\text { employment }\end{array}$ & $\begin{array}{l}\text { Author's } \\
\text { calculation: } \\
\text { Quantec }\end{array}$ & Positive \\
\hline
\end{tabular}
$-0.6 \%$ and $1 \%$. The minimum of growth rates indicates that some of the values are negative suggesting that if a need to take the logarithm of the variables arises, the logarithm of the growth rate will result in missing values for the negative values. The human capital proxies show that semi-skilled (ss) employment has the highest mean of 2445 employees,

TABLE 1: Skills classification according to profession in South Africa.

\begin{tabular}{ll}
\hline Skills level & Profession \\
\hline Skilled & - Manager \\
& - Professional \\
Semi-skilled & - Clechnician \\
& - Sales and services \\
& - Skilled agriculture \\
& - Plant and mated mine operator \\
Low-skilled & - Elementary \\
& - Domestic worker \\
\hline
\end{tabular}

Source: Statistics South Africa, 2014, Youth employment, unemployment, skills and economic growth, viewed 11 May 2018, from https://www.statssa.gov.za/presentation/Youth\%20 employement,\%20skills\%20and\%20economic\%20growth\%201994-2014.pdf.

TABLE 2: Variables, description and data sources.

Note: The study uses an annual panel data sourced from Quantec database. 
followed by low-skilled (ls) at 1061 employees and lastly the skilled (s) employees averaging 902 employees. A similar trend is reported for the standard deviation, suggesting high volatility within the semi-skilled employed labour. Physical capital has an average of R187 million and varies between 0 and $\mathrm{R} 9.8$ billion for the determined period.

Table 4 presents the correlation matrix of the variables used. Statistically significant association is reported among a majority of the variables with a positive correlation between total output and capital recording a notable $90.4 \%$. The total output is positively related with all skill levels of the employed (human capital proxies), recording correlation coefficients of $78 \%$ with skilled labour, $85 \%$ with semi-skilled labour and $59.2 \%$ with low-skilled labour. This suggests that the semiskilled labour cohort has a significantly high correlation with total output in South Africa followed by the skilled and to a lesser extent the low-skilled of the employed labour.

Similarly, a correlation matrix with output growth $(g)$ as a dependent variable shows a positive correlation between skilled employment and economic growth while reporting a negative correlation between low-skilled employment and economic growth. The weak correlation between physical capital and growth was unexpected and is not in line with Borojo and Jiang's (2015) emphasis on physical capital as a critical input for economic growth. The results of the pairwise correlation with the growth rate of output as the dependent variable are shown in Table 5.

The structure of the labour force is presented by the different skill shares of the employed people in the formal sector - as defined in Table 2. The correlation between output and shares is in line with theoretical expectation as a share of skilled employment (sh_s) is strongly positive at 31\%, followed by a share of semi-skilled (sh_ss) at $5 \%$ while a share of low-skilled (sh_ls) is negatively correlated with output (Table 4). Similar results were reported in the correlation between output growth $(g)$ and the shares in Table 5 .

These results are in line with arguments made by Diebolt and Hippe (2016) that educated labour is an enabling agent to economic growth. The positive sign between total output

TABLE 3: Summary statistics.

\begin{tabular}{|c|c|c|c|c|c|c|c|}
\hline Variables & Mean & Standard deviation & Minimum & Maximum & Variance & Skewness & Kurtosis \\
\hline Output & 941.881 & 2451.804 & 0.000 & 42073.870 & 6011345 & 6.303 & 59.819 \\
\hline$g$ & 0.028 & 0.082 & -0.609 & 1.019 & 0.00655 & 0.944 & 26.488 \\
\hline$s$ & 902.197 & 2922.796 & 0.000 & 57146 & 8542735 & 7.954 & 96.361 \\
\hline ss & 2445.326 & 5987.084 & 0.000 & 110634 & $3.58 e+07$ & 6.375 & 62.230 \\
\hline Is & 1061.220 & 2184.490 & 0.000 & 45346 & 4771994 & 5.009 & 41.570 \\
\hline capital & 187.778 & 523.608 & 0.000 & 9816.485 & 274165.3 & 6.918 & 73.243 \\
\hline empl_t & 5381.419 & 11906.570 & 0.000 & 185844 & $1.42 e+08$ & 5.342 & 43.653 \\
\hline empl_f & 4408.742 & 10121.030 & 0.000 & 139729 & $1.02 e+08$ & 5.506 & 44.790 \\
\hline empl_inf & 972.627 & 2735.989 & 0.000 & 67045 & 7485635 & 8.622 & 117.9033 \\
\hline
\end{tabular}

TABLE 4: Correlation matrix for total output.

\begin{tabular}{|c|c|c|c|c|c|c|c|c|c|}
\hline Variables & Output & empl_t & $s$ & ss & Is & $s h \_s$ & $s h \_s s$ & $s h \_l s$ & Capital \\
\hline Output & 1.000 & - & - & - & - & - & - & - & - \\
\hline empl_t & $0.832 * * *$ & 1.000 & - & - & - & - & - & - & - \\
\hline$s$ & $0.780 * * *$ & $0.821 * * *$ & 1.000 & - & - & - & - & - & - \\
\hline ss & $0.854 * * *$ & $0.963 * * *$ & $0.756 * * *$ & 1.000 & - & - & - & - & - \\
\hline Is & $0.592 * * *$ & $0.814 * * *$ & $0.521 * * *$ & $0.772 * * *$ & 1.000 & - & - & - & - \\
\hline$s h \_s$ & $0.311 * * *$ & $0.235 * * *$ & $0.447 * * *$ & $0.220 * * *$ & $0.027 * * *$ & 1.000 & - & - & - \\
\hline sh_ls & $-0.18 * * *$ & $-0.09 * * *$ & $-0.18 * * *$ & $-0.12 * * *$ & $0.248 * * *$ & $-0.375 * * *$ & $-0.31 * * *$ & 1.000 & - \\
\hline Capital & $0.904 * * *$ & $0.693 * * *$ & $0.696 * * *$ & $0.724 * * *$ & $0.499 * * *$ & $0.312 * * *$ & $0.048 * * *$ & $-0.016 * * *$ & 1.000 \\
\hline
\end{tabular}

$*, p<0.1 ; * *, p<0.05 ; * * *, p<0.01$

TABLE 5: Correlation matrix for output growth

\begin{tabular}{|c|c|c|c|c|c|c|c|c|c|}
\hline Variables & $g$ & $e m p l \_t$ & $s$ & ss & Is & $s h \_s$ & s_ss & $s h \_l s$ & Capital \\
\hline$g$ & 1.000 & - & - & - & - & - & - & - & - \\
\hline$e m p l \_t$ & 0.005 & 1.000 & - & - & - & - & - & - & - \\
\hline$s$ & $0.032 * * *$ & $0.821 * * *$ & 1.000 & - & - & - & - & - & - \\
\hline ss & 0.003 & $0.963 * * *$ & $0.756 * * *$ & 1.000 & - & - & - & - & - \\
\hline Is & -0.021 & $0.814^{* * *}$ & $0.521 * * *$ & $0.772 * * *$ & 1.000 & - & - & - & - \\
\hline$s h \_s$ & $0.070 * * *$ & $0.235 * * *$ & $0.447 * * *$ & $0.220 * * *$ & $0.027 * * *$ & 1.000 & - & - & - \\
\hline sh_ss & $0.034 * * *$ & $-0.075^{* * *}$ & $-0.041 * * *$ & $0.032 * * *$ & $-0.18 * * *$ & $0.048 * * *$ & 1.000 & - & - \\
\hline sh_ls & $-0.078 * * *$ & $-0.088 * * *$ & $-0.179 * * *$ & $-0.116^{* * *}$ & $0.248 * * *$ & $-0.375 * * *$ & $-0.31 * * *$ & 1.000 & - \\
\hline Capital & 0.001 & $0.693 * * *$ & $0.696^{* * *}$ & $0.724 * * *$ & $0.499 * * *$ & $0.312^{* * *}$ & $0.048 * * *$ & $-0.0163^{* * *}$ & 1.000 \\
\hline
\end{tabular}

$*, p<0.1 ; * *, p<0.05 ; * * *, p<0.01$. 
and total employment, as well as capital is in line with Mnif's (2016) argument that capital accumulation and labour productivity bode well for total output. These economic agents (capital and labour) are also recognised by Eicher (2000) as crucial for economic output. This study focuses on the quality embedded in labour, and the contribution of skilled, semi-skilled and low-skilled employees to economic output. The variation of the coefficients (in the different models) will inform the contribution of each of the proxies of human capital to total economic output.

Table 6 presents overall results of the panel causality test between total output and human capital (s) from lag 1 to 4 across 269 municipalities of South Africa. The study applies the hypothesis of Dumitrescu and Hurlin (2012). The proxy of skilled labour (s) is considered to be highly embedded with an educational element (compared to semi-skilled and low-skilled labour). With the panel results showing that the $p$-values of the Z-bar and Z-bar tilde statistics are significant at $1 \%$.

The results indicate that the null hypothesis of no Granger causality will be rejected as all coefficients are different from zero. The alternative hypothesis is accepted, implying that there is bidirectional causality between economic output and human capital for all panels at all four lags.

Similarly, the results presented in Table 6 indicate bidirectional causality between economic output and total employment (empl_t) for all panels of the four lags. The $p$-values of the Z-bar and Z-bar tilde statistics are statistically significant at $1 \%$ level. This led to the rejection of the null hypothesis of no Granger causality running from output to empl_t. The null hypothesis of no Granger causality running from empl_t to output is also rejected. The results confirm that total output is a causal effect for employment and that employment also propels economic output. Results from the panel causality test informed that higher levels of economic output could possibly predict a demand for skilled employment, indicating that as the economy grows, the need for skilled employees to facilitate the adoption of new technologies will increase. Also, an increased number of skilled employed bodes well for total output and total employment.

The results from Table 6 confirm a bidirectional causal relationship between total output and human capital in the formal employment sector. This suggests that a change in total output predicts a change in the skilled cohort of formal employment and also a change in the skilled cohort of formal employment will cause a change in total output. Similarly, Table 6 shows that on average a change in total output predicts a change in total employment while a change in total employment is an indicator of a change in total output in South Africa's 269 municipalities between 1993 and 2016. The results are suggestive of endogeneity between the key variables.
From the above results of the causality test, the presence of possible endogeneity led to the reliance and use of a system GMM estimation technique. A system GMM is best suited to deal with heterogeneity, heteroscedasticity and potential endogeneity issues. Each estimator has two regression results, for human capital variables at level and the different shares of skills of total employment. This section further discusses the estimations of total output and output growth in level terms in which the skill quality embedded in the labour force is used as a proxy for human capital in this study. In this regard, the formal employment sector has been divided into three constituent elements (skilled, semi-skilled and low-skilled) in order to clearly determine the contribution of each skill level to the economy. Table 7 presents the estimation of the two-step system GMM results in which total output is the dependent variable. The data is in logarithm form for both actual values and shares of each of the human capital proxies. For this study, the variables of interest are the total output, proxies of human capital (s, ss and 1s), as well as shares of each skill level in formal employment (sh_s, sh_ss and sh_ls).

The overall performance of the models displayed in Table 7 is largely satisfactory with most of the signs of the coefficients in harmony with theoretical expectation of the catalytic influence of human capital on economic output and growth (Lucas 1990; Mankiw et al. 1992). The results from the Dumitrescu and Hurlin (2012) panel causality test confirmed the existence of bidirectional causality - a possibility of endogeneity. In this regard, Yakovlev (2007) commends a system GMM application as a more robust and efficient estimator. System GMM also introduces instrumental variables to deal with endogeneity. Furthermore, Nayan, Kadir and Abdullah (2013) concur that for robust estimation, system GMM is the superior estimator.

The lagged dependent (Output_L1) coefficient in Table 7 is positive and statistically significant at $1 \%$ level showing the dynamic nature of total output. This suggests that municipalities record positive total output despite the different levels. However, the lagged dependent (g_L1) coefficient of output growth in Table 7 is statistically significant at $1 \%$ level and negative (indicating that the growth path of municipalities is moving in the same trajectory). Table 7 shows that all $p$-values of the three different skill levels $(s, s s, l s)$ are statistically significant below 0.05 . Therefore, all the three null hypotheses will be rejected and alternative hypotheses accepted. This shows that all three the different skill levels have an impact on economic output. However, the coefficients of the three different skill levels will inform if each of the skill levels has a negative or positive impact on economic output.

In line with theory, the system GMM model shows the coefficient for skilled employment as statistically significant at $1 \%$ level and with an overall positive effect on the total output. Holding other variables constant, a 1\% increase in skilled employment (s) will boost total output by $0.055 \%$. 
TABLE 6: Causality between economic output and human capital.

\begin{tabular}{|c|c|c|c|c|c|}
\hline Lag length & Panel direction & Nature of direction & Wbar statistics & Z-bar statistics & Z-bar tilde statistics \\
\hline \multicolumn{6}{|c|}{ Panel test statistics } \\
\hline \multirow[t]{2}{*}{1} & Bidirectional Causality & output $\rightarrow \mathrm{s}$ & 3.8667 & $33.2466 * * *$ & $26.7143 * * *$ \\
\hline & & $s \rightarrow$ output & 2.9408 & $22.5081 * * *$ & $17.7568 * * *$ \\
\hline \multirow[t]{2}{*}{2} & Bidirectional Causality & output $\rightarrow s$ & 4.8216 & $46.2779 * * *$ & $16.8614 * * *$ \\
\hline & & $s \rightarrow$ output & 3.8488 & $30.3222 * * *$ & $10.5190 * * *$ \\
\hline \multirow[t]{2}{*}{3} & Bidirectional Causality & output $\rightarrow$ s & 5.9231 & $58.7167 * * *$ & $12.6680 * * *$ \\
\hline & & $s \rightarrow$ output & 5.82210 & $56.6664 * * *$ & $12.1555 * * *$ \\
\hline \multirow[t]{2}{*}{4} & Bidirectional Causality & output $\rightarrow$ s & 10.5059 & $150.9025 * * *$ & $23.8126 * * *$ \\
\hline & & $s \rightarrow$ output & 11.2920 & $169.1357 * * *$ & $26.9904 * * *$ \\
\hline \multicolumn{6}{|c|}{ Causality between economic output and total employment } \\
\hline \multirow[t]{2}{*}{1} & Bidirectional Causality & output $\rightarrow$ employ_t & 6.0052 & $58.0471 * * *$ & $47.4016 * * *$ \\
\hline & & employ_t $\rightarrow$ output & 3.8690 & $33.2725 * * *$ & $26.7360 * * *$ \\
\hline 2 & Bidirectional Causality & output $\rightarrow$ employ_t & 9.2998 & $119.7251 * * *$ & $46.0564 * * *$ \\
\hline \multirow[t]{2}{*}{3} & Bidirectional Causality & output $\rightarrow$ employ_t & 12.2751 & $186.3123 * * *$ & $44.5608 * * *$ \\
\hline & & employ_t $\rightarrow$ output & 5.7083 & $54.4017 * * *$ & $11.5895 * * *$ \\
\hline \multirow[t]{2}{*}{4} & Bidirectional Causality & output $\rightarrow$ employ_t & 15.4013 & $264.4510 * * *$ & $43.6025 * * *$ \\
\hline & & employ_t $\rightarrow$ output & 9.5610 & $128.9857 * * *$ & $19.9928 * * *$ \\
\hline
\end{tabular}

Note: The null hypothesis of no causal relationship between economic output and human capital (and between human capital and economic output) is rejected at least at $1 \%$ level. Output $s$ shows causality running from economic output to human capital. S output presents causality running from human capital to total output. Skilled (S) employment is a proxy for human capital. The null hypothesis of no causal relationship between economic growth and employment (and between employment and economic growth) is rejected at least at 1\% level with *** indicating a significant $\mathrm{p}$-value at $1 \%$. Output employ_t shows causality running from economic output to employment. Employ_t output presents causality running from employment to total output.

***, significant $p$-value at $1 \%$.

TABLE 7: System generalised method of moments results. Variable

System generalised method of moments

\begin{tabular}{|c|c|c|c|c|}
\hline & \multirow{2}{*}{$\begin{array}{l}\text { Estimations of total output and human } \\
\text { capital variables and shares of } \\
\text { employment in South Africa from } \\
1993 \text { to 2016: Level }\end{array}$} & \multicolumn{3}{|c|}{$\begin{array}{l}\text { Estimation of output growth model with human capital variables and shares of employment } \\
\text { in South Africa from } 1993 \text { to } 2016\end{array}$} \\
\hline & & Shares & Level & Shares \\
\hline Output_L1 & $0.904 * * * \dagger$ & $0.905 * * *$ & - & - \\
\hline$s$ & $0.055 * * * \dagger$ & $0.046 * * * \dagger$ & $0.043 * * * \dagger$ & $0.035 * * * \dagger$ \\
\hline ss & $-0.059 * * * \dagger$ & $0.019 * * * \dagger$ & $-0.118 * * * \dagger$ & $-0.034 * * * \dagger$ \\
\hline Is & $-0.002 * * * \dagger$ & $0.024 * * * \dagger$ & $0.033 * * * \dagger$ & $0.058 * * * \dagger$ \\
\hline Capital & $0.070 * * * \dagger$ & $0.079 * * * \dagger$ & $0.033 * * * \dagger$ & $0.044 * * * \dagger$ \\
\hline empl_inf & $0.005 * * * \dagger$ & $0.019 * * * \dagger$ & $0.006 * * * \dagger$ & $0.017 * * * \dagger$ \\
\hline g_L1 & - & - & $-0.102 * * * \dagger$ & $-0.106 * * * \dagger$ \\
\hline empl_f & - & $-0.021 * * * \dagger$ & - & $-0.054 * * * \dagger$ \\
\hline Year & $0.000 * * * \dagger$ & $0.000 * * * \dagger$ & $0.000 * * * \dagger$ & $0.000 * * * \dagger$ \\
\hline Observations & 33861 & 33861 & 32367 & 32367 \\
\hline Instruments & $1.5 e+03$ & $1.5 e+03$ & $1.5 e+03$ & $1.5 e+03$ \\
\hline $\operatorname{AR}(2)$ & 0.000 & 0.000 & 0.000 & 0.000 \\
\hline Sargan $p$-value & 0.259 & 0.257 & 0.098 & 0.097 \\
\hline
\end{tabular}

Note: Dependent variable is total output. All variables are in logarithm.

$\dagger$, Robust standard errors $=0.000$.

$* * *, * *$ and $*$ indicate that coefficients are significant at $1 \%, 5 \%$ and $10 \%$.

This implies that municipalities that employ skilled labour will record a higher total output. This confirms that the employment of high-quality skills bodes well for total output (Bayraktar-Sağlam 2016). In contrast, semi-skilled and lowskilled employment have a negative contribution to total output even as they are statistically significant. This shows that a $1 \%$ increase in semi-skilled and low-skilled employment will reduce total output by $0.059 \%$ and $0.002 \%$. Similarly, Table 7 shows that at the level, skilled employment has the highest contribution to economic growth $(g)$, compared to a negative effect of semi-skilled employment. A $1 \%$ increase in skilled employment will increase output growth by 0.043 units, ceteris paribus. However, low-skilled employment begins to show a positive effect on growth over time as a $1 \%$ increase contributes 0.033 units to output growth, a notable improvement from a reduction (-0.002) reported in Table 7. This shows that the effect of low-skilled employment is realised on the growth rate of output rather than on level production (total output).

On the structure of employment, Table 7 shows that the skilled share of employment is reported as statistically significant at $1 \%$ level. A $1 \%$ increase in the skilled share of employment, ceteris paribus, will propel total output by $0.046 \%$. Similarly, in growth terms (in Table 7) a 1\% rise in the skilled share of employment will increase output growth 
by $0.035 \%$ when all other things remain constant. The contribution of the semi-skilled share of employment to total output and output growth is not consistent. A $1 \%$ increase in the semi-skilled share of employment will increase total output by $0.019 \%$ but reduce output growth by $0.034 \%$ if all other things remain constant. The low-skilled share of employment has a positive contribution to both total output $(0.024 \%)$ and output growth $(0.058 \%)$.

This suggests that while additional low-skilled employment has an immediate muting effect on the level of production (total output), the increase of the low-skilled share of employment will increase output growth over time. The results show that labour-intensive sectors that easily attract low-skilled employees are likely to record low production levels but over time the share of low-skilled employment will have a positive contribution to economic growth. System GMM results largely show a positive and statistically significant relationship between the total output and skilled employment. Skilled employment contributes $0.055 \%$ to total output, while a share of skilled employment is reported to contribute $0.046 \%$ to total output. Semi-skilled and lowskilled employment are reported to have a negative impact on total output. The negative sign for semi-skilled employment indicating a negative contribution to total output was not in line with the pairwise correlation outcome. This suggests that semi-skilled employment is not adequately equipped to have a value-generating effect on total output. A similar contribution is reported for employment shares. Overall, the results suggest that investment in high-end skill programmes to fully equip labour would bode well for the total output and output growth across municipalities in South Africa.

\section{Conclusion}

This study investigates the effect of human capital of employed labour on economic output and growth in South Africa, with a balanced panel of 269 South African municipalities for the period 1993 to 2016 . This study utilises a panel causality test and the GMM estimation techniques. Empirical literature informed that educated labour tends to have a high contribution to economic output. Human capital was proxied by different skill levels of formal employment. For the purpose of this study, human capital was defined as elements embodied in human beings that boost the quality of labour provided by the workforce through their skills and knowledge (Kleynhans 2006). The panel causality results confirm the bidirectional causality between economic output and human capital, as well between economic output and total employment.

The findings show that skilled employees have a positive effect on both economic output and economic growth. These results concur with empirical findings by Pegkas and Tsamadias (2014) that education (investment embodied in human beings) increases labour productivity and therefore has a positive effect on economic output both at level and growth rate. The results show that on average, skilled employment in different economic sectors across municipalities in South Africa yields a higher value than semi-skilled and low-skilled employment. These findings confirm the positive effect of human capital in the form of skilled employment on economic output and economic growth.

Empirical findings from this study inform that skilled labour has the highest contribution to total output (even though with fewer employees) compared to semi-skilled and low-skilled labour. In line with this, Ghalandarzehi and Safdarie (2012) argue that a positive relationship between human capital and economic growth is mainly witnessed when the economic structure of the country is able to attract, employ or absorb and retain skilled labour. For policy direction, it is recommended that the government implement skills development policies (training scarce competitive skills to their work force) in order to upwardly shift a significant share of the semi-skilled and low-skilled employees to the highly skilled cohort. The initiative by government to revitalise technical and vocational education and training colleges is applauded if the quality of training meets the requirements of potential employers in different industries. This will ensure the realisation of one of the identified strategic interventions (improving skills and human capital formation) to develop a more competitive and diversified economy (NDP 2011). Following the progress on the Millennium Development Goal 2 of universal primary education, it is recommended that the government should also target education spending on medium and high skills to ensure progression beyond primary education. The implementation of free higher education to deserving beneficiaries is welcome as an increased number of people will progress beyond primary education.

In this study, the authors investigated only employed labour and not the entire labour force. Another area of research may be to include the unemployed skilled labour in order to appreciate forgone economic value. As a result of limited data prior to 1993, the study could not assess if the effect of skills on economic growth was the same prior to the democratic government.

\section{Acknowledgements Competing interests}

The authors declare that they have no financial or personal relationships that may have inappropriately influenced them in writing this research article.

\section{Authors' contributions}

N.N., C.S.S. and N.G.M. contributed equally to this article.

\section{Ethical considerations}

This article followed all ethical standards for research without direct contact with human or animal subjects. 


\section{Funding information}

This research received no specific grant from any funding agency in the public, commercial or not-for-profit sectors.

\section{Data availability}

Data sharing is not applicable to this article as no new data were created or analysed in this study.

\section{Disclaimer}

The views and opinions expressed in this article are those of the authors and do not necessarily reflect the official policy or position of any affiliated agency of the authors.

\section{References}

Abbas, Q., 2001, 'Endogenous growth and human capital: A comparative study of Pakistan and Sri Lanka', The Pakistan Development Review 40(4), 987-1007. https://doi.org/10.30541/v40i4llpp.987-1007

Acemoglu, D., 2009, Introduction to modern economic growth, Princeton University Press, viewed 11 May 2018, from https://press.princeton.edu/ titles/8764.html

Arellano, M. \& Bond, S., 1991, 'Some tests of specification for panel data: Monte Carlo evidence and an application to employment equations', The Review of Economic Studies 58(2), 277-297. https://doi.org/10.2307/2297968

Arellano, M. \& Bover, O., 1995, 'Another look at the instrumental variable estimation of error-components models', Journal of Econometrics 68(1), 29-51.

Awad, A., Halid, N. \& Yussof, I., 2013, 'The impact of human capital on economic growth: The case of selected Arab countries', International Journal of West Asian growth: The case of selected Arab countries, International
Studies 5

Bassanini, A. \& Scarpetta, S., 2002, 'Does human capital matter for growth in OECD countries? A pooled mean group approach', Economics Letters 74(3), 399-405. https://doi.org/10.1016/S0165-1765(01)00569-9

Barro, R.J., 2001, 'Human capital and growth', American Economic Review 91(2), 12-17. https://doi.org/10.1257/aer.91.2.12

Barro, R.J. \& Lee, J.-W., 1993, 'International comparisons of educational attainment' Journal of Monetary Economics 32(3), 363-394. https://doi.org/10.1016/0304 3932(93)90023-9

Baum, C.F., Schaffer, M.E. \& Stillman, S., 2003, 'Instrumental variables and GMM Estimation and testing', The Stata Journal 3(1), 1-31. https://doi. org/10.1177/1536867X0300300101

Bayraktar-Sağlam, B., 2016, 'The stages of human capital and economic growth: Does the direction of causality matter for the rich and the poor?', Social Indicators Research 127(1), 243-302. https://doi.org/10.1007/s11205-015-0963-0

Becker, G.S., Murphy, K.M. \& Tamura, R., 1990, 'Human capital, fertility, and economic growth', Journal of Political Economy 98(5, Part 2), S12-S37. https://doi. org/10.1086/261723

Benhabib, J. \& Spiegel, M., 1994, 'The role of human capital in economic development evidence from aggregate cross-country data', Journal of Monetary Economics 34(2), 143-173. https://doi.org/10.1016/0304-3932(94)90047-7

Bhorat, H., Cassim, A. \& Tseng, D., 2016, 'Higher education, employment and economic growth: Exploring the interactions', Development Southern Africa 33(3), 312-327. https://doi.org/10.1080/0376835X.2016.1161501

Bils, M. \& Klenow, P.J., 2000, 'Does schooling cause growth?', American Economic Review 90(5), 1160-1183. https://doi.org/10.1257/aer.90.5.1160

Blundell, R. \& Bond, S., 1998, 'Initial conditions and moment restrictions in dynamic panel data models', Journal of Econometrics 87(1), 115-143. https://doi. org/10.1016/S0304-4076(98)00009-8

Blundell, R., Dearden, L., Meghir, C. \& Sianesi, B., 1999, 'Human capital investment: The returns from education and training to the individual, the firm and the economy', Fiscal Studies 20(1), 1-23. https://doi.org/10.1111/j.1475-5890.1999. tb00001.x

Borensztein, E., Gregorio, J.D. \& Lee, J.W., 1998, 'How does foreign direct investment affect economic growth?', Journal of International Economics 45(45), 115-135. https://doi.org/10.1016/S0022-1996(97)00033-0

Borojo, D.G. \& Jiang, Y., 2015, 'The impact of human capital on economic growth in Ethiopia', Journal of Economics and Sustainable Development 6(16) 109-118.

Borojo, D.G. \& Jiang, Y., 2016, 'The impact of Africa-China trade openness on technology transfer and economic growth for Africa: A dynamic panel data approach', Annals of Economics and Finance 17(2), 403-431.

Denison, E.F., 1985, Trends in American economic growth, 1929-1982, Brookings Institution, Washington, DC, viewed 11 May 2018, from https://trove.nla.gov.au/ work/17781970?q\&versionld=20858392
Diebolt, C. \& Hippe, R., 2016, The long-run impact of human capital on innovation and economic development in the regions of Europe 7 Association Française de Cliométrie (AFC), viewed 11 May 2018, from https://econpapers.repec.org/ paper/afcwpaper/07-16.htm

Dumitrescu, E.I. \& Hurlin, C., 2012, 'Testing for Granger non-causality in heterogeneous panels', Economic modelling 29(4), 1450-1460. https://doi.org/10.1016/j. econmod.2012.02.014

Easterly, W., 2001, The elusive quest for growth: Economists' adventures and misadventures in the tropics, MIT Press, Cambridge, MA.

Eicher, T., 2000, 'Inequality and growth: The dual role of human capital in development', CESifo Working Paper Series, CESifo Group Munich, viewed 11 May 2018, from https://ideas.repec.org/p/ces/ceswps/_355.html

Engelbrecht, H.-J., 2003, 'Human capital and economic growth: Cross-section evidence for OECD countries', Economic Record 79(Special Issue), S40-S51. https://doi. org/10.1111/1475-4932.00090

Fedderke, J., De Kadt, R. \& Luiz, J., 2003, 'Capstone or deadweight? Inefficiency, duplication and inequity in South Africa's tertiary education system, 1910-93', Cambridge Journal of Economics 27(3), 377-400. https://doi.org/10.1093/cje/27.3.377

Frankel, J., Smit, B. \& Sturzenegger, F., 2008, 'South Africa: Macroeconomic challenges after a decade of success', Economics of Transition 16(4), 639-677. https://doi. org/10.1111/j.1468-0351.2008.00341.x

Ghalandarzehi, K. \& Safdarie, M., 2012, 'Role \& status of educated human resources (human capital) on economic growth of Iran', International Journal of Business and Social Science 3(11), 164-172.

Gyimah-Brempong, K., Paddison, O. \& Mitiku, W., 2006, 'Higher education and economic growth in Africa', The Journal of Development Studies 42(3), 509-529. https://doi.org/10.1080/00220380600576490

Hanushek, E.A., Schwerdt, G. \& Wiederhold, S., 2015, 'Returns to skills around the world: Evidence from PIAAC', European Economic Review 73, 103-130. https:// doi.org/10.1016/j.euroecorev.2014.10.006

Howitt, P. \& Aghion, P., 1998, 'Capital accumulation and innovation as complementary factors in long-run growth', Journal of Economic Growth 3(2), 111-130. https:// doi.org/10.1023/A:1009769717601

Imbs, J., 2013, 'The premature deindustrialization of South Africa', in J. Esteban, J. Stiglitz, \& J. Lin Yifu (eds.), The industrial policy revolution II, pp. 529-540, Palgrave Macmillan UK, London.

Kleynhans, J., 2006, 'The role of human capital in the competitive platform of South African industries', SA Journal of Human Resource Management 4(3), 55-63. https://doi.org/10.4102/sajhrm.v4i3.100

Lucas, R.E., 1988, 'On the mechanics of economic development', Journal of Monetary Economics 22(1), 3-42. https://doi.org/10.1016/0304-3932(88)90168-7

Lucas, R.E., 1990, 'Why doesn't capital flow from rich to poor countries? The American Economic Review', American Economic Association 80(2), 92-96.

Mahadea, D. \& Simson, R., 2010, 'The challenge of low employment economic growth in South Africa: 1994-2008', South African Journal of Economic and Management in South Africa: 1994-2008', South African Journal of Economic and Management
Sciences 13(4). http://www.scielo.org.za/scielo.php?script=sci_arttext\&pid $=$ S2222-34362010000400002

Mankiw, N.G., Romer, D. \& Weil, D.N., 1992, 'A contribution to the empirics of growth', The Quarterly Journal of Economics 107(2), 407-437. https://doi. org/10.2307/2118477

Mnif, S., 2016, 'Skill-biased technological change: The case of the Mena Region', Economic Annals 61(210), 101-116. https://doi.org/10.2298/EKA1610101M

Murphy, K.M., Shleifer, A. \& Vishny, R.W., 1991, 'The allocation of talent: Implications for growth', The Quarterly Journal of Economics 106(2), 503-530. https://doi. org/10.2307/2937945

National Planning Commission, 2011, 'National Development Plan: Vision for 2030', no. RP270/2011, viewed 11 May 2018, from https://www.gov.za/sites/default/ files/gcis_document/201409/devplan2.pdf

Nayan, S., Kadir, N. \& Abdullah, M.S., 2013, 'Revisiting energy consumption and GDP: Evidence from dynamic panel data analysis', Procedia Economics and Finance 7, 42-47. https://doi.org/10.1016/S2212-5671(13)00216-5

Nelson, R.R. \& Phelps, E.S., 1966, 'Investment in humans, technological diffusion, and economic growth', The American Economic Review 56(1/2), 69-75.

Pegkas, P. \& Tsamadias, C., 2014, 'Does higher education affect economic growth? The case of Greece', International Economic Journal 28(3), 425-444. https://doi. org/10.1080/10168737.2014.894551

Petrakis, P.E. \& Stamatakis, D., 2002, 'Growth and educational levels: A comparative analysis', Economics of Education Review 21(5), 513-521. https://doi.org/10.1016/ S0272-7757(01)00050-4

Pritchett, L., 2001, 'Where has all the education gone?', The World Bank Economic Review 15(3), 367-391. https://doi.org/10.1093/wber/15.3.367

Romer, P.M., 1990, 'Endogenous technological change', Journal of Political Economy 98(5), S71-102. https://doi.org/10.1086/261725

Rosenzweig, M.R., 1990, 'Population growth and human capital investments: Theory and evidence', Journal of Political Economy 98(5), S38-S70.

Schwab, K., 2017, 'The global competitiveness report', viewed 11 May 2018, from http://www3.weforum.org/docs/GCR2016-2017/05FullReport/TheGlobal CompetitivenessReport2016-2017_FINAL.pdf

Solow, R.M., 1956, 'A contribution to the theory of economic growth', The Quarterly Journal of Economics 70(1), 65-94. https://doi.org/10.2307/1884513 
Solow, R.M., 1957, 'Technical change and the aggregate production Function', The Review of Economics and Statistics 39(3), 312-320. https://doi.org/10.2307/1926047

South African Reserve Bank, 2009, South African Reserve Bank quarterly bulletin Pretoria, viewed 11 May 2018, from https://www.resbank.co.za/Publications/ Detail-Item-View/Pages/Publications.aspx?sarbweb=3b6aa07d-92ab-441f-b7bfbb7dfb 1 bedb4\&sarblist $=21$ b5222e-7125-4e55-bb65-56fd3333371e \& sarbitem $=8334$

South African Reserve Bank, 2018, Online statistical query (historic macroeconomic timeseries information), South African Reserve Bank, viewed 11 May 2018, from https://www.resbank.co.za/Research/Statistics/Pages/OnlineDownloadFacility. aspx

Statistics South Africa, 2014, Youth employment, unemployment, skills and economic growth, viewed 11 May 2018, from https://www.statssa.gov.za/presentation/ Youth $\% 20$ employement, \%20skills\%20and\%20economic\%20growth\%2019942014.pd
Statistics South Africa, 2016, Gross domestic product, Pretoria, viewed 11 May 2018, from http://www.statssa.gov.za/publications/P0441/P04414thQuarter2016.pdf

The World Bank, 2015, World development indicators 2015, Washington, DC, viewed 11 May 2018, from http://documents.worldbank.org/curated/en/795941468 338533334/World-development-indicators-2015

Van der Berg, S., Burger, C., Burger, R., De Vos, M., Du Rand, G., Gustafsson, M. et al, 2011, Low quality education as a poverty trap, Department of Economics, University of Stellenbosch, Stellenbosch.

Verspoor, A., 1990, 'Educational development: Priorities for nineties', Finance and Development 27(1), 20-23.

Witherick, M., 1999, The urban world: Processes and issues, Stanley Thornes, London.

Yakovlev, P., 2007, 'Arms trade, military spending, and economic growth', Defence and Peace Economics 18(4), 317-338. https://doi.org/10.1080/10242690601099679 